\title{
Downgrading Financial Service Delivery and Institutional Sustainability: A Case Study of Akwapim Rural Bank, Ghana
}

\author{
Owuraku Sakyi-Dawson, \\ Department of Agricultural Extension, University of Ghana, Legon \\ Email: osakyid@gmail.com
}

Cynthia Odonkor,

P. O. Box MB 510 Ministries, Accra, Ghana

Email: cyodonkor@yahoo.co.uk

and

Ramatu Mahama Al-Hassan, Department of Agricultural Economics and Agribusiness, University of Ghana.

Email:ramatu_mahama@yahoo.com

DOI: http://dx.doi.org/10.4314/gjds.v11i1.2

\begin{abstract}
Rural financial markets in the developing world are faced with the problem of information asymmetry and are monopolistically competitive. Based on this, one policy option to enhance rural clients' access is for formal financial institutions to mimic products and services of informal intermediaries. Empirical evidence on impact of mimicry on institutional sustainability can help improve policy choices, yet there is a dearth of studies on this. Using time series data to analyse trends in selected financial ratios and means this study examines the impact that the mimicking of an informal financial product by a formal financial institution (Rural Bank) has on the outreach and sustainability. The time series data was collected from the bank's financial statements and returns to the central bank between 1996 and 2005. It was found that adoption of informal financial product enhanced outreach and sustainability of the bank. This study, demonstrates that the mimicry policy option if adopted by formal financial institutions can enhance availability of financial services to the productive poor and also lead to long-term sustainability of financial institutions.
\end{abstract}


Key Words: Downgrading, Rural Finance, Informal Financial Products, Institutional Sustainability, Financial Products and Services

\section{Introduction}

Access to financial services has been identified to be important for growth and poverty reduction since it enables people to accumulate funds in a secure place over time and build their productive assets by enabling them to invest in micro enterprises, education, health among others to improve their productivity and income. It also helps households to cope with negative income shocks (Dercon, Bold \& Calvo, 2006). Financing productive micro enterprises is particularly important for poverty reduction since a greater percent of poor earners in developing countries are either employed by or own a micro enterprise (Westley, 2001). However, a greater proportion of the rural households in developing countries lack access to financial services. Majority of these people depend on the informal sources of finance to meet their livelihood and consumption needs (Sinha, 2005). In a study conducted by Ageba and Amha (2006), it was found that, most of the medium and small enterprises use friends and relatives as their major source of finance rather than going to bank for a loan.

The poor tend to be concentrated in harder-to-reach rural areas characterized by weak and fragmented markets for goods and services, dispersed populations, limited non-farm activities and underdeveloped infrastructures. These factors imply both relatively higher costs and greater risk of lending. Other factors implying relatively high administrative costs are the difficulties inherent in identifying and reaching poor persons and the heavy delegation and monitoring costs resulting from the lack of physical collateral (Conning, 1999). The lack of physical collateral in turn implies higher credit risk. In short, delivering financial services to the poor is comparatively costly and difficult, and is fraught with risk, none of which augurs well for long term financial self-sufficiency of the intermediary (Armendáriz de Aghion \& Morduch, 2005). Due to these problems, formal financial institutions consider the poor as non-bankable. As such, most of the poor and micro entrepreneurs depend on informal financial intermediaries such as money lenders and susu collectors for their financial service needs. Despite the vibrant informal financial markets in many developing countries, financial services to the poor still remain inadequate (Zellar \& Sharma, 2000). This is because the informal financial intermediaries from whom most micro entrepreneurs seek financial services have limited resources to provide the appropriate range of financial services needed by the rural sector. They are also constrained in the services they can offer since they lack the breadth, depth and term transformation to provide the full and appropriate range of financial services needed by the rural poor (Nwanna, 1996). The formal intermediaries on the other hand, enjoy economy of scale and can mobilize large amounts of deposits for lending. They have extensive infrastructures and systems and access to funds. 
One of the theoretical arguments on the rural financial markets takes the view that, the sector is faced with the problem of imperfect information with respect to screening, incentives and enforcement (Hoff \& Stiglitz, 1993). It stresses the importance of cost and imperfect information in rural financial intermediation due to information asymmetry which results in problems with respect to screening of loan applicants, providing incentives and enforcing actions to ensure repayment by the borrower (Hoff \& Stiglitz, 1993). Bell (1990) demonstrates that imperfect information or imperfect contract enforcement generates the possibility of loan default and eventually problems of credit rationing. The informal financial intermediaries have a cost advantage over the formal in addressing the information asymmetry in that, they operate close to rural clients and have less costly mechanisms for information gathering and enforcing repayments such as kinship, shorter social and physical distances (geography) and inter-linked market relationships (Hoff \& Stiglitz, 1993). As such, they use these as cheaper screening and credit rationing mechanism (Aleem, 1990). The formal financial intermediaries are usually far away from rural or poor clients, and as such collecting information about the clients involves a high transaction cost (Hoff \& Stiglitz, 1993). Due to these problems, they rely on collateral based lending technologies to screen borrowers and enforce contracts. As such, borrowers with little or no acceptable collateral are often credit rationed (Balkenhol \& Schutte, 1996). The rural financial markets are in effect monopolistically competitive in favour of the informal intermediaries.

One policy option that emerges from the monopolistically competitive paradigm of rural financial markets is for the formal financial intermediaries in rural areas to mimic the products and services of the informal intermediaries (that is the downscale of their operations) to meet the needs of the productive poor especially in the rural areas of developing countries (Seibel, 1999; Hoff \& Stiglitz, 1993). The advantages of mimicking or copying the products and services of the informal financial services providers is because cost advantage enables them to gather information on clients at a cheaper cost and also develop products with attributes which are more suitable for the rural clients. Therefore their adoption by the formal intermediaries enables the latter to use services and products that already address the information asymmetry problem in the rural areas. A number of formal financial institutions have adopted some of the products and services of the informal financial intermediaries through downgrading their operations. The evidence suggests that, this has enhanced outreach to the rural entrepreneurs (Seibel, 2001). For the mimicry policy option to be attractive to formal financial intermediaries, their policy makers need to be convinced of the benefits to their institutions. However, few studies have been conducted to assess the impact of the adoption of informal products by formal financial institutions in general and the Susu product in particular on the performance of those financial institutions. Even the few studies do not dwell much on the performance and sustainability of the financial institutions that are downgrading their operations. This study therefore examined the effects of the downgrading the operations of Akwapim Rural Bank through the use of the Akusika susu Scheme on the performance of the bank's outreach and sustainability. 


\section{Profile of the Akusika susu product of Akwapim Rural Bank}

Akwapim Rural Bank is one of the 137 Rural and Community Banks in Ghana. In Ghana, Rural and Community Banks are community owned unit banks established in rural areas. They operate through their network of agencies. The Rural Banking system was started in 1976 to provide financial access for rural communities through the banking system. Currently, Rural and Community banks in Ghana operate under the Banking Act 673 (2004).

Akwapim Rural Bank was established in 1980 with its head office at Mamfe Akuapem in the Eastern Region of Ghana. Currently, it has six agencies or branches within the Akuapem North and South Districts. Some of the products of the bank include normal savings, students' savings, fixed deposit, current account, banking on wheels among others. In 2001, the bank introduced a financial product based on the traditional Susu collection concept as one of its saving mobilisation /credit products to attract clients in the informal sector who are not able to access the bank's main products. The traditional Susu collection concept operates in a way whereby an individual susu collector (agent) goes to the premises or workplace of the client on daily basis to collect saving deposits. The deposit collection is a 31-day cycle where the client decides to contribute a fixed amount daily. At the end of the month/ cycle, the client receives his/her deposit back less a day's contribution as the collector's commission.

The bank named the product Akusika susu scheme and linked the savings mobilization to clients ability to access credit. The minimum daily contribution was GHфo.10. Clients who decide not to take their deposit at the end of the month have their full 31 day's contribution saved in their account while those who take their money at the end of the month are charged a day's contribution as commission. A continuous contribution for three months without withdrawals qualifies a client for credit. The loan amount approved is equivalent to almost three times the clients' three month accumulated savings and this savings is used as loan. Credit delivery under the scheme is based on the individual lending methodology, with a loan size of between GH\$25.00 - GH\$1,200.00. Clients taking more than $\mathrm{GH} \$ 1$, ooo are required to provide between one and four salary account holders of the bank to serve as guarantors in addition to their loan. Loan repayment is through the daily deposit made by the borrower and repayment period is over a maximum period of one year.

\section{Methodology}

This research was designed using the control group method (before and after comparison) suggested by Hulme (2000). This method was selected to help address the problem of attribution. Time series data was obtained from the audited financial statements of Akwapim Rural Bank and extracts from the returns the bank submitted to the Banking Supervision Department (BSD) of the Bank of Ghana. The study was conducted between October 2006 and June 2007. The data used for this study was for the period between 1996 
and 2005 since that was the audited financial statements available. Since the product was introduced in 2001, the study period was taken as five years before and five year after the introduction of the product. Other secondary data such as the inflationary rate, treasury bill rate, lending rate and nominal GDP figures were obtained from the annual reports of the Bank of Ghana for over the same period.

The data was analysed using financial ratios appropriate for the indicators considered. The ratios were selected based on a framework developed by the Small Enterprise Education and Promotion (SEEP) Network for measuring the performance of microfinance institutions (Isabelle et al, 2005). The choice of the ratios used for the study was influenced by the requirement for sound theoretical reasoning and the immediate availability of data for the chosen time period. The nominal values were adjusted for inflation using the GDP deflator with 1996 as the base year to correct for inflation and enhance the year-to-year comparison.

Using the indicators of outreach, portfolio quality, efficiency, productivity, profitability and self-sufficiency, the bank's performance before and after the introduction of the Akusika susu scheme was compared.

Trends in the selected performance indicators were used in the analyses. In addition, the mean of the indicators were compared by testing for statistical significance in differences between them, five years before and five years after the adoption of the Susu product using the Student's t-test at $\mathrm{p} \leq 0.05$ significance level.

\section{Findings}

\section{Contribution of the Akusika Susu Product to the Bank's Savings Deposit Mobilization}

Knowledge of the contribution of the Akusika susu product to the bank's savings and loans portfolio gives an indication of the importance of the product to the financial institution. With clients of Akusika susu product increasing from 7 percent to 17 percent of the bank's active savers between 2001 and 2004, their contribution to the bank's savings mobilised also increased from 12 percent to 65 percent of the bank's total value of savings mobilised over the same period (Table 1). The number of active savers dropped in 2005 (Table 1) due to management decision to put on hold the registration of new clients and the granting of new loans to enable the management assess the product's impact and also strengthen the internal control measures before further expansion. The average savings balance per saver of the Akusika susu product in real value increased from GH $\$ 53.90$ in 2001 to GH $\$ 193.70$ in 2005 with an annual average of GH\$119.40. However, that of the other savings product decreased in real value from $\mathrm{GH} \$ 30.00$ in 2001 to $\mathrm{GH} \$ 19.20$ in 2005 with an annual average of GH $\$ 22.28$ (Table 1). This may bebecause majority of the clients who were saving through the Akusika susu did not withdraw their savings at the end of the month, whilst those 
using the banks other savings products might have been withdrawing. This therefore depicts the increasing importance of the informal product to savings mobilisation drive of the bank.

Table 1: Percentage of savings mobilized through the Akusika susu product and real average savings balances

\begin{tabular}{|c|c|c|c|c|c|c|c|c|}
\hline \multirow{2}{*}{$\begin{array}{l}\text { Year } \\
\text { (31st } \\
\text { Dec.) }\end{array}$} & \multicolumn{2}{|l|}{ Akusika } & \multicolumn{2}{|c|}{ Other deposit products } & \multirow{2}{*}{$\begin{array}{l}\text { \% of } \\
\text { Savings } \\
\text { from } \\
\text { Akusika }\end{array}$} & \multirow{2}{*}{$\begin{array}{l}\% \\
\text { Akusika } \\
\text { clients }\end{array}$} & \multicolumn{2}{|c|}{$\begin{array}{l}\text { Real av. Savings } \\
\text { balance per saver } \\
(\mathrm{GH} \Phi)\end{array}$} \\
\hline & $\begin{array}{l}\text { Real } \\
\text { Deposit } \\
\text { mobilized } \\
(\mathrm{GH} \pitchfork)\end{array}$ & $\begin{array}{l}\text { No. of } \\
\text { clients }\end{array}$ & $\begin{array}{l}\text { Real } \\
\text { Deposit } \\
\text { Mobilized } \\
(\mathrm{GH} \downarrow)\end{array}$ & $\begin{array}{l}\text { No. of } \\
\text { clients }\end{array}$ & & & Akusika & $\begin{array}{l}\text { Other } \\
\text { products }\end{array}$ \\
\hline 2001 & $48,887 \cdot 30$ & 907 & $358,200.00$ & 11,940 & 12.01 & 7.06 & 53.90 & 30.00 \\
\hline 2002 & $148,571.70$ & 1,927 & $461,897.00$ & 16,615 & 24.35 & 10.39 & 77.10 & 27.80 \\
\hline 2003 & $468,266.40$ & 3,912 & $311,715.60$ & 18,123 & 59.98 & 17.75 & 119.70 & 17.20 \\
\hline 2004 & $650,076.00$ & 4,260 & $357,381.60$ & 20,778 & 64.56 & 17.01 & 152.60 & 17.20 \\
\hline 2005 & $641,534.40$ & 3,312 & $490,118.40$ & 25,527 & 56.68 & 11.48 & 193.70 & 19.20 \\
\hline Average & $391,467.16$ & 2,863 & $395,862.52$ & $18,596.60$ & $43 \cdot 52$ & 12.74 & 119.40 & 22.28 \\
\hline
\end{tabular}

Source: Authors' computation (2007), based on data from the end of year returns and financial statement of Akwapim Rural Bank.

\section{Contribution of the Akusika Product to the Bank's Loan Portfolio}

For the five-year period of its existence, the product contributed between 16 percent and 75 percent to the total loan portfolio of the bank with an average of 49 percent over the five-year period (Table 2).

Table 2: Distribution of amount of loans disbursed in real value

\begin{tabular}{|l|l|l|l|l|}
\hline $\begin{array}{l}\text { Year } \\
\text { ending } 3^{\text {st }} \\
\text { December }\end{array}$ & Akusika product & Other products & $\begin{array}{l}\text { Total loans } \\
\text { disbursed }\end{array}$ & $\begin{array}{l}\text { \% Akusika } \\
\text { product }\end{array}$ \\
\hline 2001 & $22,597.80$ & $121,494.50$ & $144,092.30$ & 15.68 \\
\hline 2002 & $83,647.33$ & $179,780.08$ & $263,427.40$ & 31.75 \\
\hline 2003 & $243,694.30$ & $83,290.09$ & $326,984.40$ & 74.53 \\
\hline
\end{tabular}




\begin{tabular}{|l|l|l|l|l|}
\hline 2004 & $266,899.60$ & $122,611.51$ & $389,511.11$ & 68.52 \\
\hline 2005 & $214,098.41$ & $175,578.45$ & $389,676.87$ & 54.94 \\
\hline Mean & $166,187.49$ & $136,550.93$ & $302,738.41$ & 49.09 \\
\hline
\end{tabular}

Source: Authors' computation (2007) based on data from the end of year returns and financial statement of Akwapim Rural Bank.

\section{Effect of Akusika Susu Product on Outreach of the Bank}

Breadth of outreach, measured as the percentage change in the number of active borrowers and active savers of the bank's clients increased after the informal product was introduced. Before the akusika susu product was introduced (1996-200o), the bank's active borrowers grew on average by 79 percent while the number of active savers grew on average by 47 percent. After the introduction of the product, that is (2001-2005), the bank's active borrowers grew on average by 98 percent with the number of active savers growing on average by 124.5 percent (Fig. 1). There was a negative growth rate for active borrowers in 2005 due to management's intervention to put on hold the granting of new loans to allow for the evaluation of the product and possible modification of the features as loan officer case load was increasing beyond manageable limits.

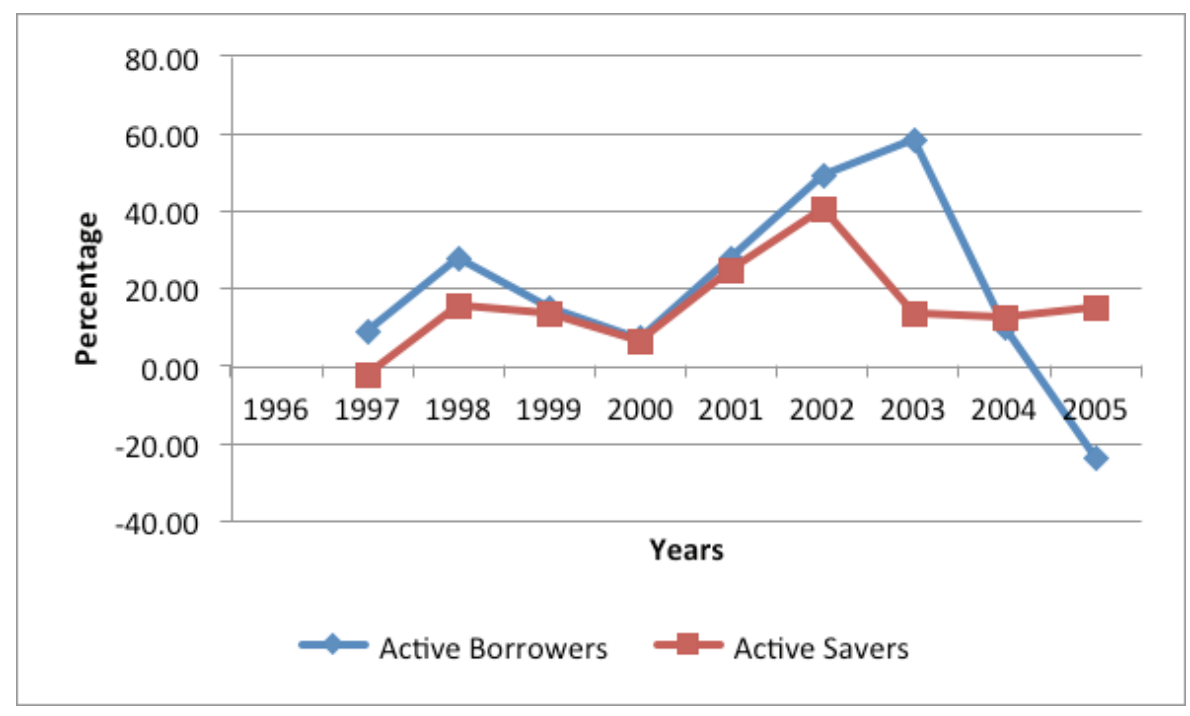

\section{Figure 1: Growth rate in outreach}

Source: Authors' computation (2007) from the audited accounts of the Bank.

Figure two shows that, the real average savings balance per saver increased throughout the study period with the period after the introduction of the product showing greater 
increase than the period before. The mean real average savings balance per saver for the period before the introduction of the product was lower (GH\$9.29) compared to the one after the introduction of the product (GH\$13.16). However, the difference did not reach statistical significance (Table 3).

Table 3: Mean outreach and sustainability indicators before and after the introduction of the Akusika susu product

\begin{tabular}{|c|c|c|c|c|}
\hline Measure & Indicator & Mean before & Mean after & $\mathrm{t}-\mathrm{cal}$ \\
\hline \multirow{2}{*}{ Outreach } & $\begin{array}{l}\text { Average loan size per } \\
\text { borrower }(\mathrm{GH} \Phi)\end{array}$ & 32.4 & $29 \cdot 3$ & -0.10 \\
\hline & $\begin{array}{l}\text { Average savings deposit } \\
\text { balance per saver }(\mathrm{GH} \Phi)\end{array}$ & 9.2 & 13.2 & 0.42 \\
\hline \multirow{2}{*}{ Portfolio Quality } & PAR>30 days (\%) & 8.30 & 7.67 & -0.08 \\
\hline & Loan Loss Reserve Ratio & 2.33 & 4.09 & $5.91^{* *}$ \\
\hline \multirow{4}{*}{$\begin{array}{l}\text { Efficiency and } \\
\text { productivity }\end{array}$} & Operational Expense Ratio & 0.57 & 0.46 & $-38.04^{* * *}$ \\
\hline & $\begin{array}{l}\text { Institutional Efficiency } \\
\text { Ratio }(\%)\end{array}$ & 0.73 & 0.29 & $-27.09^{* * *}$ \\
\hline & Cost per Borrower (GHథ) & 18.6 & 14.1 & -0.33 \\
\hline & $\begin{array}{l}\text { Personnel Productivity } \\
\text { (numbers) }\end{array}$ & 391.72 & 505.73 & 0.18 \\
\hline \multirow{2}{*}{ Profitability } & ROE (\%) & 47.96 & 42.28 & 0.15 \\
\hline & $\mathrm{ROA}(\%)$ & 35.76 & 29.95 & -0.14 \\
\hline \multirow{2}{*}{$\begin{array}{l}\text { Financial } \\
\text { strength }\end{array}$} & $\begin{array}{l}\text { Operational Self-Sufficiency } \\
\text { ratio }(\%)\end{array}$ & 101.95 & 136.29 & 0.17 \\
\hline & $\begin{array}{l}\text { Financial Self-Sufficiency } \\
\text { ratio (\%) }\end{array}$ & 61.81 & 80.55 & 1.65 \\
\hline
\end{tabular}

** 5 percent significance ${ }^{* * *} 1$ percent significance

Between 1996 and 2000 before the Akusika susu product was introduced, the real average loan size per borrower of the bank ranged between GH\$28.49 and GH\$36.52. After the introduction of the product, it was ranging between GH\$26.31 and GH\$35.94. The annual mean real average loan size per borrower for the period before and after the inception of the scheme was GH\$32.44 and GH\$29.39 respectively. Thus, the average amount of loan received per client reduced after the introduction of the product, implying that increasing numbers of borrowers with relatively smaller loan sizes are being served. 


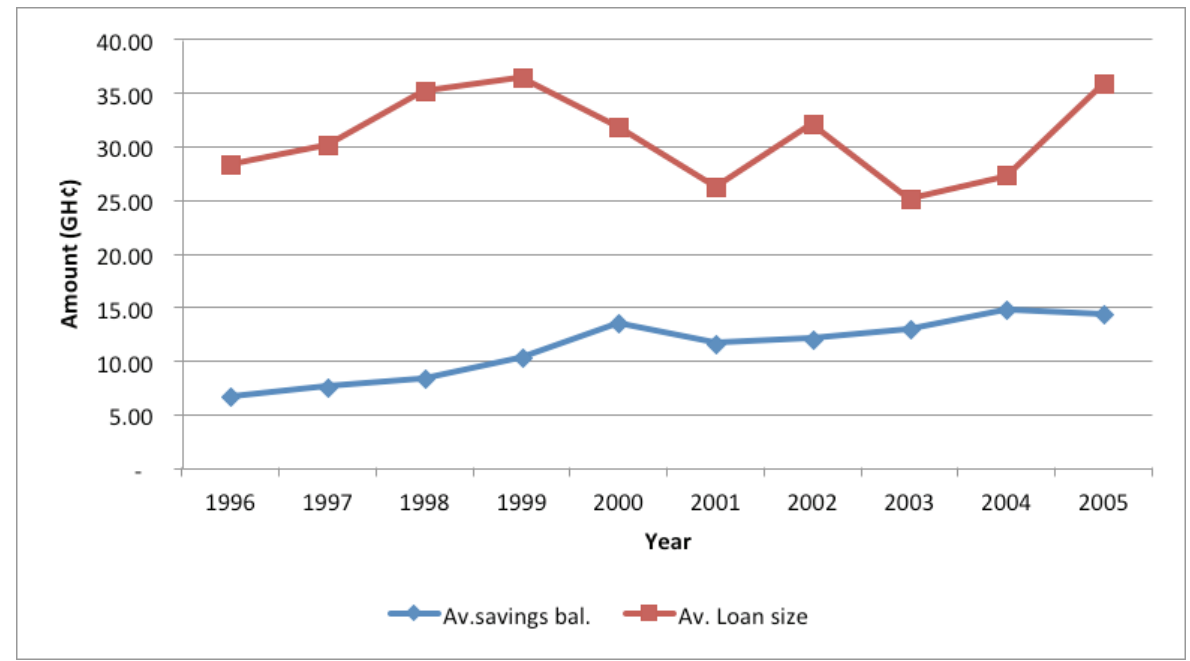

Figure 2: Trends in average savings and loan balances

Source: Authors' computation (2007) from the audited accounts of the Bank.

\section{Financial Sustainability of the Bank}

The bank's financial sustainability was assessed using the indicators of efficiency and productivity, portfolio quality, profitability and financial strength.

\section{Efficiency and Productivity}

The efficiency and productivity of the bank was measured using indicators such as Operational Expense Ratio (OER), Institutional Efficiency Ratio (IER), Cost per Borrower (CPB) and Personnel Productivity (PP).

The OER is measured as operating expense divided by average gross portfolio. Institutional Efficiency Ratio (IER), is measured as the sum of interest expense, loan loss provision and administrative expense divided by average gross loan portfolio. Cost per Borrower $(\mathrm{CPB})$ is measured as the operating expense divided by number of active borrowers and Personnel Productivity (PP) is measured as number of active clients divided by total number of staff.

A decreasing trend in OER and IER indicates improvement in the management of the institution's expenses. 
Figure three shows the Operational Expense Ratio (OER) decreased after the introduction of the informal product. The bank recorded a mean OER of 0.57 before and 0.46 after the introduction of the product. The mean difference for the two periods was significant at $\mathrm{p} \leq .001$ (Table 3). The Institutional Efficiency Ratio (IER) trend also decreased after the introduction of the Akusika susu scheme. The mean IER for the period before was 0.73 and this decreased to 0.29 after the introduction of the scheme. The mean difference was significant at 1 percent level (Table 3). The results from the two ratios suggest an improvement in the bank's operating efficiency after the product was introduced.

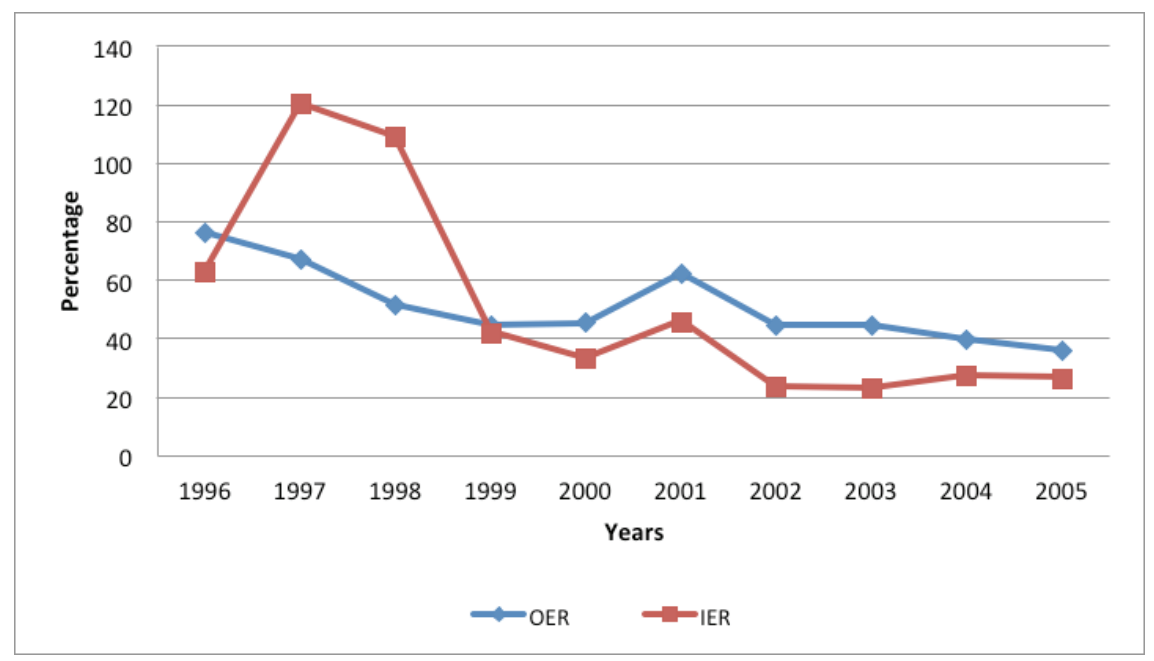

\section{Figure: Operational efficiency}

Source: Author's computation (2007) based on data from the end of year returns of the Bank.

The average cost per borrower in real value before the introduction of the product ranged between $\mathrm{GH} \$ 21.97$ and $\mathrm{GH} \$ 15.03$ with an average of $\mathrm{GH} \$ 18.61$ and after the introduction of the product, it was ranging between $\mathrm{GH} \$ 17.07$ and $\mathrm{GH} \$ 15.33$ with a period average of GH $\$ 11.61$ (Table 4).

The trend in the Personnel Productivity (PP) ratio which shows the productivity of the institution's staff increased from a ratio of 367 accounts per staff in 1996 to 527 in 2005 that is, the staff were handling more clients after the introduction of the product. The period average of clients per personnel was 392 and 506 before and after the introduction of the product respectively (Table 4). 
Table 4: Efficiency and productivity of the bank

\begin{tabular}{|l|l|l|}
\hline Year ending 31st December & Personnel productivity & Real cost per borrower (GH $)$ \\
\hline 1996 & 367 & 21.97 \\
\hline 1997 & 295 & 20.71 \\
\hline 1998 & 374 & 18.57 \\
\hline 1999 & 424 & 16.80 \\
\hline 2000 & 500 & 15.03 \\
\hline Mean (Before) & 392 & 18.62 \\
\hline 2001 & 484 & 17.07 \\
\hline 2002 & 532 & 14.79 \\
\hline 2003 & 514 & 11.61 \\
\hline 2004 & 472 & 11.77 \\
\hline 2005 & 527 & 15.33 \\
\hline Mean (After) & 506 & 14.12 \\
\hline & & \\
\hline
\end{tabular}

Source: Author's computation (2007) based on data from the end of year returns and audited accounts of the bank.

\section{Portfolio Quality}

The portfolio quality was measured using the indicators, portfolio at risk greater than 30 days $\left(\mathrm{PAR}_{30}\right.$ ) measured as the sum of portfolio at risk greater than 30 days and renegotiated loans divided by gross loan outstanding. The $\mathrm{PAR}_{30}$ increased from 2.3 percent in 1996 to a peak value of 28 percent in 2001; it then declined sharply to 11.9 percent in 2002 and by 2005, the PAR $_{30}$ was approximately 8 percent (Fig. 4). The trend showed an improvement in the portfolio quality after the introduction of the Akusika product with average $\mathrm{PAR}_{30}$ reducing from 8.3 percent before to 7.7 percent after the introduction of the product. This could be attributed to the daily collection method for loan repayment used under the susu methodology. 


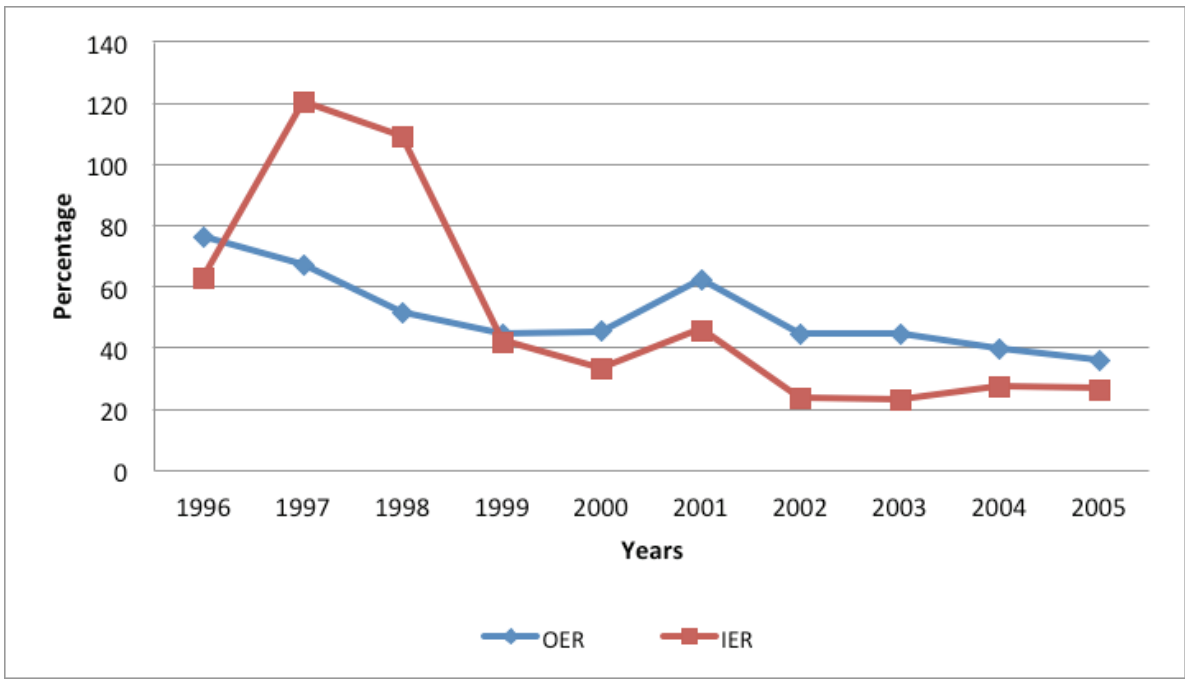

\section{Figure 4: Portfolio quality}

Source: Author' computation (2007) based on data from the end of year returns of the Bank

\section{Profitability}

The indicators of profitability used for the analysis are the Return on Assets (ROA) and Return on Equity (ROE). These indicators were compared with the 91-day Treasury Bill rate which is the alternative use of funds for the bank's investors have they not invested in the bank. The results show that apart from 1996 and 1997, the ROE and the ROA of the bank were high above the 91-day Treasury Bill rate (Fig. 5). Comparing the period before and after the introduction of the Akusika product, the results showed that before the product's introduction, shareholders had an average of 12 percent return more by owing equity in the bank instead of investing in the 91-day Treasury Bills but this increased to 21 percent after the introduction of the Akusika product (Table 5). In terms of the returns on the bank's total assets, before the Akusika product was introduced there was a deficit return of -0.17 percent compared with the return obtained on Treasury bill. However, after the introduction of the product, the average return on assets was 9.4 percent more than the average return to be obtained by investing in treasury bills (Table 5). 


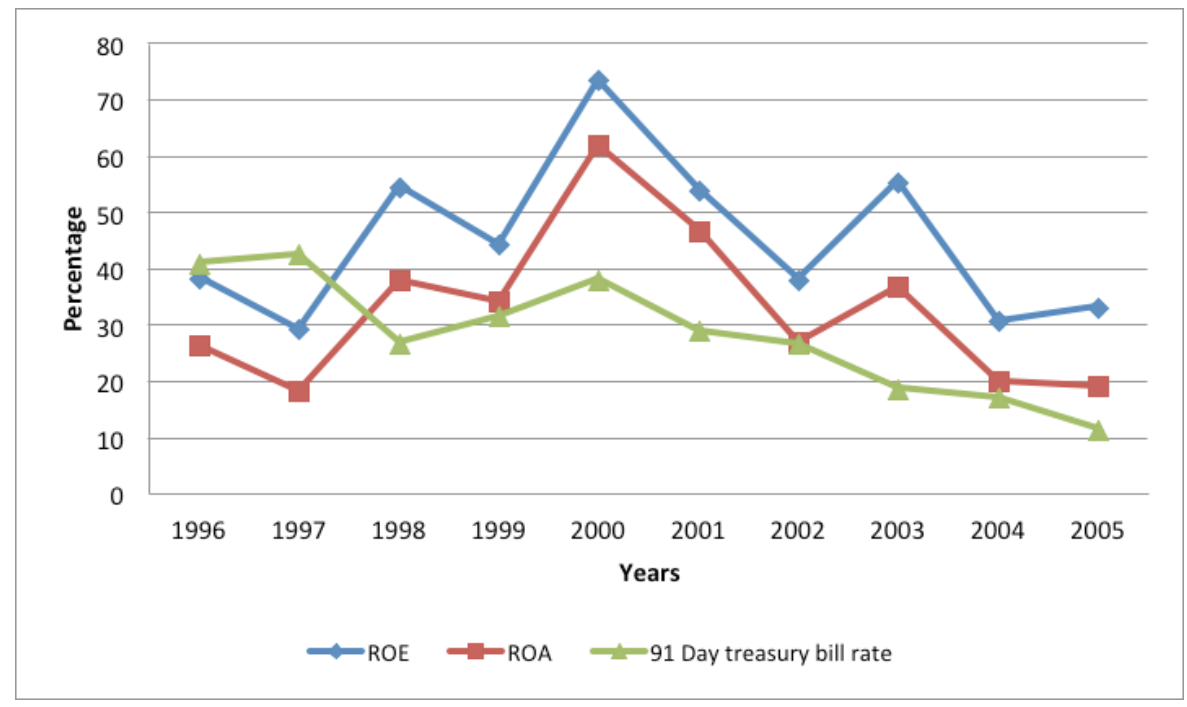

\section{Figure 5: Profitability}

Source: Author's computation (2007) based on data from the annual reports of the Bank

Table 5: Profitability before and after the introduction of the product

\begin{tabular}{|l|l|l|l|l|l|}
\hline $\begin{array}{l}\text { Year (31 } \\
\text { December) }\end{array}$ & ROE (\%) & ROA (\%) & $\begin{array}{l}\text { 91 Day } \\
\text { treasury bill } \\
\text { rate (\%) }\end{array}$ & $\begin{array}{l}\text { ROE-T-bill } \\
\text { Rate }\end{array}$ & $\begin{array}{l}\text { ROA-T-bill } \\
\text { rate }\end{array}$ \\
\hline 1996 & 38.37 & 26.31 & 40.9 & -2.53 & -14.59 \\
\hline 1997 & 29.29 & 18.32 & 42.48 & -13.19 & -24.16 \\
\hline 1998 & 54.52 & 37.96 & 26.75 & 27.77 & 11.21 \\
\hline 1999 & 44.20 & 34.29 & 31.5 & 12.70 & 2.79 \\
\hline 2000 & 73.41 & 61.91 & 38 & 35.41 & 23.91 \\
\hline Average (Before) & 47.96 & 35.76 & 35.93 & 12.03 & -0.17 \\
\hline 2001 & 54.00 & 46.76 & 28.9 & 25.10 & 17.86 \\
\hline 2002 & 38.08 & 26.93 & 26.6 & 11.48 & 0.33 \\
\hline 2003 & 55.45 & 36.75 & 18.7 & 36.75 & 18.05 \\
\hline 2004 & 30.67 & 20.06 & 17.1 & 13.57 & 2.96 \\
\hline 2005 & 33.19 & 19.23 & 11.45 & 21.74 & 7.78 \\
\hline
\end{tabular}




\begin{tabular}{|l|l|l|l|l|l|}
\hline Average (After) & 42.28 & 29.95 & 20.55 & 21.73 & 9.40 \\
\hline
\end{tabular}

Source: Author's computation (2007), based on data from the annual reports of Akwapim Rural Bank

Clearly all the indicators of profitability shows that the period after the introduction of the informal products has been associated with significantly higher levels of profitability than before its introduction by the bank.

\section{Financial Strength}

The financial strength of the bank was assessed using the Operational Self-sufficiency (OSS) ratio and Financial Self-sufficiency (FSS) ratio. Operational Self-sufficiency is measured as the operating income divided by the sum of operating expense, financing cost and provision for loan loss. Financial Self-sufficiency (FSS) ratio is also measured as the operating income divided by the sum of operating expense, financing cost, provision for loan loss and cost of capital

The trend in the operational self-sufficiency ratio reduced from 124.8 percent in 1996 to 80 percent in 1999 before rising steadily to 167 percent in 2000, since then, it has been reducing steadily reaching 125 percent in 2005. The average OSS before the introduction of the product was 101.95 percent and 136.29 percent after the introduction of the product. However, there was no significant difference between the mean OSS before and after the introduction of the scheme (Table 3).

The bank has not been financially self-sufficient throughout the study period even though there was improvement in the ratio after the introduction of the scheme. The financial self-sufficiency (FSS) ratio for the period before the inception of the informal product varied between 51.6 percent and 72.9 percent (Fig. 6) with a period average of 61.8 percent. After the introduction of the product, the ratio ranged between 72.7 percent and 88.1 percent with a period average of 80.6 percent. 


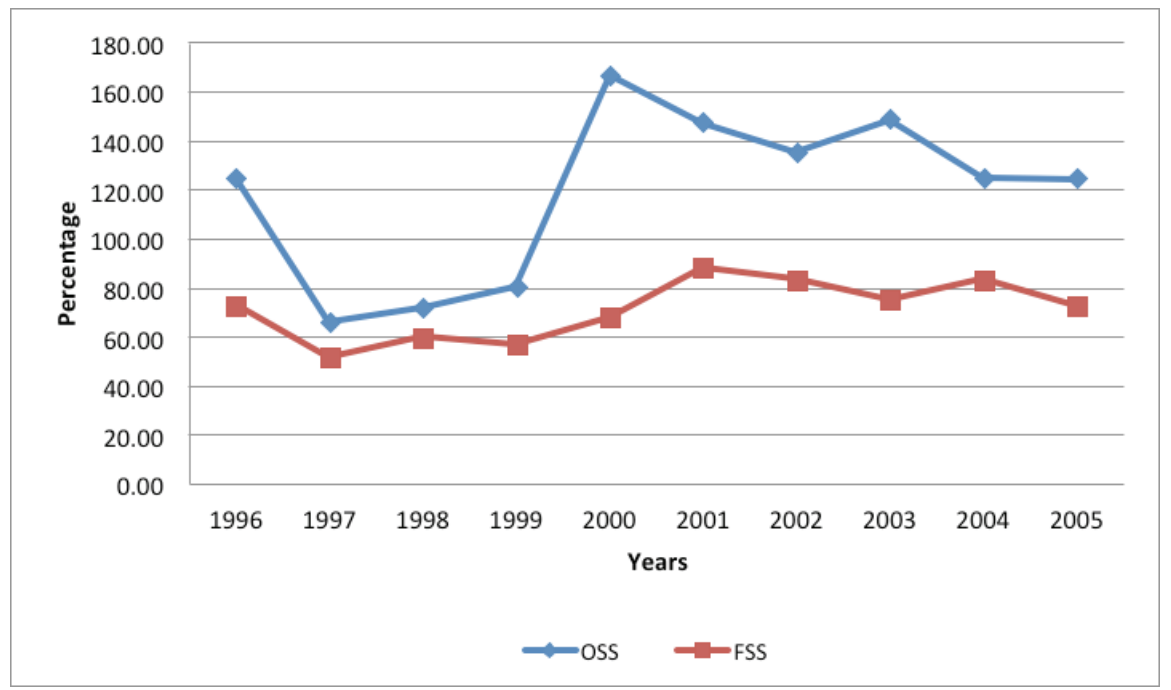

\section{Figure 6: Financial strength}

Source: Author's computation (2007) based on data from the annual reports of the Bank

\section{Discussion}

This study examined the effects of mimicking the products of informal financial service providers on the performance of formal financial institutions using Akwapim Rural Bank as case study. Trends and means of selected financial ratios were used as indicators to assess the bank's performance. The results showed that the introduction of the Akusika susu product by the bank, has enabled the bank to improve upon its performance significantly in terms of savings mobilized, portfolio quality, profitability, outreach and efficiency.

The bank's outreach improved as the number of clients served and the real average savings balance per saver increased while the mean real average loan size per borrower reduced after the Akusika product was introduced. The reduction in the real average loan size per borrower gives an indication that more poor people were able to access credit from the bank after the introduction of the Akusika susu product. This supports the suggestion by (Seibel, 1999; Hoff and Stiglitz, 1993) that, if formal financial institutions downscale their operations to meet the demand of micro entrepreneurs, they will be able to reach out to more of the underserved population. The increase in the real average saving balance is good for the institution's growth and sustainability. This is because there has been much evidence to show that savings mobilized by local financial institutions are the main source of growth of funds which make the institutions independent of external subsidies and interference (Rutherford, 2000). 
Efficiency in the bank's operations improved as evidenced from the decreasing trend in the operational expense ratio and the institutional efficiency ratio after the introduction of the Akusika susu product. All these are indications of improvement in the management of the bank's operational cost after the introduction of the scheme. The improvement might be due to the effect of economy of scale since the bank was able to extend its services (savings and credit) to more clients after the introduction of the product. The methodology of collecting daily deposits at the doorstep of the clients enabled more clients to be reached at a lower cost. The result is consistent with the findings from a study by Seibel (1998) which revealed that when the Himalaya Finance and Savings Company (HFSC) in Nepal introduced the doorstep collection of small savings and linked credit to savings, its outreach to low income groups was greatly increased, was able to offer lower interest rates credits to the low income groups and manage its risk better.

The trend in the staff productivity was positive, increasing from a ratio of 367 clients per staff in 1996 to 527 clients per staff in 2005. The period average of clients per personnel was 392 clients and 506 clients before and after the introduction of the product respectively. The results when compared with that of African reporting microfinance institutions, shows that the bank's personnel are very productive. The personnel productivity for the reporting microfinance institutions in West Africa in terms of borrowers per staff member is 177 and 300 savers per staff member. In Africa, average borrowers and savers per staff was 143 and 213 respectively while globally, average clients per staff of reporting microfinance institutions was 139 borrowers per staff and 149 savers per staff (Lafourcade, Isern, Mwangi \& Brown 2005).

For a good portfolio quality, the internationally accepted PAR $_{30}$ is 10 percent or below (Lafourcade et al, 2005). Globally, microfinance institutions continue to demonstrate low PAR > 30 days, of an average of 5.2 percent for the reporting microfinance institutions and average PAR > 30 days of 4.0 percent for reporting microfinance institutions in Africa (Lafourcade et al, 2005). The result from this study indicates that, even though the average for both periods is higher than the global value, the bank's portfolio quality in terms of $\mathrm{PAR}_{30}$ improved after the introduction of the product reducing from an annual average of 8.3 percent before to 7.7 percent after the introduction of the Akusika product. The improvement might be attributed to the appropriateness of the product methodology adopted by the bank, as well as the improvement in the macro-economic conditions in Ghana during the period. The frequent repayment instalments made it easier for the borrower to pay back their loan, confirming the assertion by Patten and Rosengard (1991) that shorter loan terms or frequent payment of instalments can make it easier for borrowers to repay their loans. The borrowers were also given repayment incentives, including pardoning part of the final interest payment if all repayments are received before the due date, speeding-up subsequent loan approvals, and increasing borrowers' credit limits if repayments are made on time. All these measures taken by the bank might have contributed to the improvement in the loan repayment as well as the portfolio quality after the introduction of the product. 
With reference to the bank's profitability, the results show that apart from 1996 and 1997, the bank's ROE and ROA were high above the treasury bill rate. Thus, investing in the bank yielded more returns than investing in the 91-day Treasury Bill. The results also indicates that, the bank became more profitable and thus likely to be more attractive to investors after the introduction of the Akusika product as the returns on equity and assets were higher and above that obtained by investing in treasury bills.

The annual average of the operational self-sufficiency and financial self-sufficiency ratios increased after the introduction of the product. Before the introduction of the product, the bank was operationally self-sufficient for only two years. However, it became operationally self-sufficient throughout the period after the introduction of the Akusika product. Even though the bank was not financially self-sufficient, its financial selfsufficiency ratio improved after the introduction of the product. This gives an indication that, with the sustainability of the Akusika product the bank would be able to attain financial self-sufficiency where it would be able to cover both its direct and indirect operational cost.

The findings from the study showed improvement in outreach, financial strength, portfolio quality, operational and financial self-sufficiency as well as a reduction in the cost of service delivery, implying that the introduction of the Akusika susu product by the bank can eventually make it financially sustainable.

\section{Conclusion}

This study has shown that if formal financial intermediaries in the rural areas downgrade their operations by adopting some of the products and practices of the informal financial intermediaries like the traditional susu system, they are likely to be able to expand outreach by serving more of the underserved population in the rural communities. It would also enable the institutions become sustainable in the long term if the macroeconomic environment of the country is favourable.

Based on the results from this study, it makes economic sense for formal financial institutions operating in the rural areas to adopt informal financial services products that already exist in the communities as product innovation. Such innovations can enhance the sustainability and outreach of these rural financial institutions. 


\section{References}

Ageba, G. \& Amha, W. (2006). Micro and Small Enterprises (MSEs) finance in Ethiopia: empirical evidence. Eastern Africa Social Science Research Review, 22(1), pp. 63-86.

Aleem, I. (1990). Imperfect Information, Screening, and the Costs of Informal Lending: A Study of a Rural Credit Market in Pakistan. World Bank Economic Review, 4(3), pp. 329-349.

Armendáriz de Aghion, B. \& Morduch, J. (2005). The Economics of Microfinance. Massachusetts: MIT Press Cambridge, pp. 346.

Balkenhol, B. \& Schutte, H. (1996). Collateral, Collateral Law and Collateral Substitutes. Geneva: International Labor Office.

Bell, C. (1990). Interactions between institutional and informal credit agencies in rural India. World Bank Economic Review, 4(3), pp. 297-327.

Conning, J. (1999). Outreach, Sustainability and Leverage in Monitored and Peer Lending. Journal of Development Economics, 6o, pp.51-77.

Dercon, S., Bold, T. \& Calvo, C. (2006). Insurance for the poor? Susatainable Development Department Technical Papers Series, No. POV-115. Washington D.C.: Inter-American Development Bank.

Hoff, K., \& Stiglitz, J. E. (1993). Imperfect information and rural credit markets: Puzzles and policies perspectives. In K. Hoff, A.Bravermen\& Stiglitz, J.E. (Eds.) (1993) The Economics of Rural Organization: Theory, Practice and Policy:(33-52) Washington: World Bank.

Hulme D. (2000). Impact assessment methodologies for Microfinance: Theory, experience and better practice. World Development, 28(1), pp 79-98.

Isabelle B., Tillman B., Lynne C., Ana E., Elena P. N., Dan N., Beth P., Blaine S.,\& Maria S. (2005). Measuring performance of microfinance institutions: A framework for reporting, analysis and Monitoring. Washington DC: the SEEP Network and Alternative Credit Technologies, USA.

Lafourcade A.L., Isern J., Mwangi P. \& Brown M. (2005). Overview of the Outreach and Financial Performance of Microfinance Institutions in Africa, www.mixmarket.org

Nwanna, G. I. (1996). Rural financial markets in West Africa: Roles, experiences, constraints and prospects for promoting Rural Development. Baltimore: Department of Economics, Morgan State University, Maryland.

Patten, R. \& Rosengard, J. (1991). Progress with Profits: The Development of Rural Banking in Indonesia. San Francisco: ICS Press. 
Rutherford, s. (2000). The poor and their money. Oxford: Oxford University Press.

Seibel, H. D. (1998). Recent Developments in Microfinance. Working paper / University of Cologne, Development Research Center, No. 1998-5.

Seibel, H.D. (1999). Strategies for Developing Viable Microfinance

Institutions with Sustainable Services: The Asian Experience. Working paper / University of Cologne, Development Research Center, No. 1999,10.

Seibel, H. D. (2001). Mainstreaming Informal Financial Institutions. Journal of Development Entrepreneurship. 6(1), pp. 83-95.

Sinha, F. (2005). Access, Use and Contribution of Micro finance in India. Economic and Political Weekly, 40(17), pp. 1714-1719.

Westley, G.D. (2001). Can Financial Market Policies Reduce Income Inequality? Sustainable Development Department Technical Paper Series, No MSM-112. Washington, D.C.

Zeller, M. \& Sharma, M. (2000). Many Borrow, More Save, and All Insure: Implications for Food and Micro Finance Policy. Food Policy Number 25, IFPRI. 